Volume 4 Nomor 1, Januari-Juni 2020: hlm. 67-80.

Fakultas Hukum, Universitas Lampung,

Bandar Lampung, Lampung, Indonesia.

E-ISSN: 2598-3105 P-ISSN: 2723-2581

http://jurnal.fh.unila.ac.id/index.php/cepalo

\title{
CHEMICAL CASTRATION FROM CRIMINAL LAW AND HUMAN RIGHTS
}

\section{Dina Silvia Puteri ${ }^{1}$, Denita Cahyanti Wahono ${ }^{2}$, Rr. Jannatul Firdaus ${ }^{3}$, Steven Sukamdani $^{4}$}

${ }^{1}$ Fakultas Hukum Universitas Airlangga, Email: dina.silvia.puteri-2019@fh.unair.ac.id

${ }^{2}$ Fakultas Hukum Universitas Airlangga, Email: denita.cahyanti.wahono-2019@fh.unair.ac.id

${ }^{3}$ Fakultas Hukum Universitas Airlangga, Email: rr.jannatul.firdaus-2019@fh.unair.ac.id

${ }^{4}$ Fakultas Hukum Universitas Airlangga, Email: steven.sukamdani-2019@fh.unair.ac.id

Submitted: April 24, 2020; Reviewed: May 20, 2020; Accepted: June 2, 2020

DOI: 10.25041/cepalo.v4no1.1910

\section{Abstract}

Chemical castration is an additional penalty for child sexual abuse stipulated under Protection of Children Law, which states that anyone who intentionally commits sexual violence against children in any way and with certain criminal elements is subject to additional penalties in the form of chemical castration. As an additional penalty, chemical castration is excessive and deprives the right to reproduction. The criminal application also explicitly overrides state protection of human rights based on international conventions such as the ICCPR and UNCAT 1948 which has been ratified by Indonesia Human Rights Law. The implementation of chemical castration in Indonesia may able to reduce the number of habitual crimes or recidivists on sexual offender still raise the pros and cons. On the other hand, the effectiveness of this method in preventing these crimes is still debatable. The Indonesian Doctors Association (IDI) rejects the assignment of the execution because the additional penalty execution by the doctor is in contrary to the Indonesian Medical Ethics Code. This study aims to find solutions to conflict of law that occur in the application of chemical castration in the perspective of criminal law and human rights.

Keywords: Castration, Child, Penalty, Recidivist.

\section{A. Introduction}

Chemical castration is a form of punishment violating Human Rights, one of which is the right to reproduce as stipulated in Article 4 of the Law 39 of 1999 regulates Human Rights Law. Meanwhile, the chemical castration took the right to reproduce, in which the injection of drugs using anaphrosidiac used to lower the sexual desire. ${ }^{1}$ With regard to human rights, chemical castration has the effect of potentially committing a form of violation. Considering that Indonesia has declared as a country that upholds the respect for the human rights on every citizen, the state should reconsider the formulation of castration punishment for criminal

\footnotetext{
${ }^{1}$ Jin Zhuang, "CHEMICAL CASTRATION: INTERNATIONAL EXPERIENCE AND CHINESE PATH TO CONTROL PEDOPHILIA CRIMES," Advances in Applied Sociology 8, no. 8 (2018): 575-597, 576, DOI: 10.4236/aasoci.2018.88034.
} 
offenders. Through the values stated in Pancasila, the second precept means that the state must be fair to every citizen and uphold humanity. The Constitution of the Republic Indonesia 1945 , states constitutionally in the chapter of human rights, that everyone has the right to life and the right to be free from torture or treatment that degrading human dignity. Chemical castration is considered as a form of torture for the perpetrators of this crime, because the punishment applied should not focus on revenge. The punishment given must have benefits for both parties (perpetrator and victim).

Within the time, there are 2 (two) kinds of castration applied in various countries, namely physical castration and chemical castration. Physical castration is carried out by amputating the testicles of pedophile perpetrators to make the perpetrators lack testosterone which will affects their sexual desire. Meanwhile chemical castration, the executor will injects antiandrogen chemicals that can weaken the hormone testosterone which can be through pills or injections. ${ }^{2}$ The hypothesis is, if the testosterone hormone weakens, the erectile ability, libido, or sexual desire of a person will decrease or even disappear altogether, so that the crime of sexual violence does not occur. It can be seen that the purpose of the castration punishment is revenge. There is no visible benefit in providing guidance to the perpetrator of a criminal act. As time goes by, the purpose of crime is no longer a means of revenge. But the purpose of the punishment given is to restore the situation to normal. This concept is called restorative justice. Restorative justice focuses on developing the perpetrators to become better individuals. This chemical castration can indeed have an effect on the perpetrator not to repeat his actions. But this will become a new criminological factor in other crimes.

Chemical castration was enforced forcibly against sexual offenders, which enforce castration as part of treatment, not punishment. According to the FDA, this MPA injection can disrupt reproductive organ function in the offender, in addition, it will also cause more serious problems that are difficult to predict. It appears that there is no certainty about the clear impact that chemical castration will cause in the future. Of course this is dangerous for the survival of a person (the perpetrator) and in the worst conditions chemical castration can result in death. Surely this is an excessive punishment and threatens the right to life of a person. When referring to the constitution, the right to life is a right that cannot be damaged under any circumstances.

In this research journal, the conflict of law of chemical castration will be discussed from the perspective of criminal law and human rights and provide a suggestion on Indonesian regulations regarding chemical castration in terms of human rights and to consider chemical castration as a treatment option in rehabilitation by reviewing regulations regarding chemical castration in other countries. ${ }^{3}$ Chemical castration is regulated on Law Number 17 Year 2016 regulates the Stipulation of Government Regulation in Amendment of Law Number 1 Year 2016 regulates Second Amendment to Law Number 23 Year 2002 regulates Child Protection Into the Act (referred as Law 17/2016), implicitly in Article 81 and 81A.

The enactment of Law 17/2016 was highlighted from the rejection from the Indonesian Doctors Association (IDI) as an executor in the application of chemical castration as an additional crime. This is important to discuss because the castration penalty for perpetrators of sexual harassment must be reviewed comprehensively with the concepts of criminal law, because if there is an error in the law regarding the basis for providing castration punishment in criminal law. So this chemical castration punishment must be reviewed and revised in

\footnotetext{
${ }^{2}$ Kartono Kartono, Aji Mulyana, "THE IMPLEMENTATION OF CHEMICAL CASTRATION PENALTIES TOWARDS PAEDOPHILIA CRIME PERPETRATORS," Fiat Justisia: Jurnal Ilmu Hukum 13, no. 4 (2019): 321-332, 324, DOI: 10.25041/fiatjustisia.v13no4.1683.

3 Yohanes Usfunan, Jimmy Z. Usfunan, and IPR. Arsha Putra, "THE CONSTITUTIONALITY OF CASTRATION SANCTION,” Udayana Journal of Social Sciences and Humanities (UJoSSH) 1, no. 1 (2017): 121-126, 123, DOI: 10.24843/UJoSSH.2017.v01.i01.p20.
} 
accordance with the theories contained in the criminal law. In addition to analysis based on criminal theories, further investigation is needed regarding the relevance of chemical castration punishment with the concept of human rights. It is very important because punishment must remain within the corridor of the law in accordance with human rights.

In this study, the Doctrinal Research type of legal research is to produce a systematic explanation of the legal rules governing a particular legal category and analyze the relationship between legal rules that explain difficult fields. This research is a legal research compiled using a statutory approach, conceptual approach and case approach. The statutory approach is carried out by examining all laws and regulations relating to the legal issues being handled. ${ }^{4}$ The case approach is the main approach in this paper, because in this problem it cannot be done in general. A detailed review must be presented in order to show that the law has played a role as an instrument that is useful in presenting justice and order in society.

\section{B. Discussion}

\section{Chemical Castration Reviewed from Criminal Law Perspective}

\section{a. Chemical Castration Purposes}

Penalty can be interpreted as a criminal sentence accompanied by sanctions as a legal consequence of criminal act committed by someone. In penalty there are several theories including absolute theory, retribution theory, relative theory, and combined theory. ${ }^{5}$ According to in the set of criminal objectives, two things must be included, firstly it must accommodate more or less the aspirations of the people who demand revenge as a compensation based on the degree of wrongdoing of the offender and the second must include the objective of punishment in the form of maintaining people's solidarity, and penalty must directed to maintain people's unity. ${ }^{6}$ From the objectives of the conviction, which is an approach that emphasizes the conditions for creating justice and balance for the perpetrators of crime and their own victims. ${ }^{7}$ In connection with the problem of chemical castration punishment, the castration punishment that is applied tends to follow the absolute theory flow.

The elements stipulated in the explanation have been fulfilled that there are already many people who want castration to be present in solving sexual crimes against children. Furthermore, in terms of the second element, namely maintaining the solidarity of the people. The castration penalty fulfills this element. The legislators, in this case the Representative Body (DPR), assess the urgency of the presence of castration to reduce the pressure of the people. The objectives that have been stated regarding this matter focus on justice and aspects of balance between perpetrators and victims. According to the author, the castration penalty for the perpetrator does not reflect justice at all. Criminal acts committed by the perpetrators are not classified as serious crimes, such as corruption, terrorism and genocide. However, the punishment for the perpetrator of sexual offenses against children greatly reduces the dignity of the perpetrator as a human being. In relation to the balance aspect stated in the theory of punishment, the writer thinks that castration has a balance between the punishment imposed on the perpetrator and the impact suffered by the child as a victim of sexual abuse. The impact

\footnotetext{
${ }^{4}$ Marzuki, Peter Mahmud, Penelitian Hukum (Kencana: Jakarta, 2005), 133.

${ }^{5}$ Krismiyarsi Krismiyarsi, "STUDY OF PENAL POLICY ON CHEMICAL CASTRATION SANCTION ON CHILD SEXUAL CRIMES CASES IN INDONESIA," IJCLS (Indonesian Journal of Criminal Law Studies) 3, no. 2 (2018): 121-132, DOI: 10.15294/ijcls.v3i2.17171.

${ }^{6}$ Moeljatno, Asas-asas Hukum Pidana (Jakarta: Rineka Cipta, 2008), 57.

7 Vedije Ratkoceri, "CHEMICAL CASTRATION OF CHILD MOLESTERS - RIGHT OR WRONG?!," European Journal of Social Sciences Education and Research 11, no. 1 (2017): 70-76, 74, DOI: 10.26417/ejser.v11i1.p70-76.
} 
that the child feels in a sexual abuse case is tremendous. Depression and trauma will certainly be felt by child victims of sexual abuse. The time spent recovering the child's condition will be very long and must go through consistent recovery efforts.

This theory states that the severity of criminal sanctions must be balanced with the wrongdoing of the perpetrators known as the principle of no criminal offense without error (geen straft zander schuld), therefore it is forbidden to impose criminal sanctions on an innocent person. However, in practice, the principle of proportionality is relative because judges in proving the element of error are confronted with facts which are variables that must be taken into account in order to measure someone's mistakes. While in other cases it is only said to be proportionate if the type of serious crime is committed. ${ }^{8}$ Analysis based on this theory in the issue of castration punishment is very important. The castration penalty for the perpetrator must fulfill the guilt element of the article imposed on the perpetrator. Do not let the punishment of castration be imposed on innocent people, because it will seriously injure the sense of justice in society. The competence of law enforcment must be paid close attention to avoiding wrong arrests.

The application of the principle of proportionality is very subjective in its application. The judge's view is very influential in determining the punishment for the perpetrators. The sense of justice in each individual judge is a crucial factor in enforcing this castration law. The objectivity of the judge is absolutely present in every case related to cases of sexual abuse against children, because in this case not only the rights of the victims need to be protected but the rights of the perpetrators also need to be protected.

Based on the explanation of the proportional principle, Indonesia supports the concept of criminal restorative justice. PAF Lamintang (1997: 183-193) divided the criminal acts contained in the Criminal Code (KUHP) into subjective and objective elements. Based on subjective elements, to impose a sentence is not enough if there is a criminal offense but there must be someone who can be punished or known as a strafbaar persoon. ${ }^{9}$ On the other hand there are additional circumstances that arise after certain acts have been carried out but are not included in the additional conditions for the conviction of a person (bijkomende voorwarde van strafbaarheid), in which without the additional conditions the defendant has committed a crime, which can be prosecuted for the conviction criminal sanctions as threatened, but with the existence of these additional circumstances, the criminal threat is then weighted. ${ }^{10}$ Based on the first element revealed by PAF Lamintang, it is clear that there are people who have committed criminal acts of child sexual abuse. Given the crime of sexual abuse against children is not a category of crime without victims. Besides that, the second element in the opinion explains that if there is a situation that arises after the occurrence of a criminal act, then the judge can consider the existence of additional criminal threats that can be added to the perpetrator. If it related to the problems in this paper, there is a relevance in the emergence of castration punishment in the criminal act of child sexual abuse. Castration punishment arises because of additional circumstances beyond the perpetrator's actions against the victim. This situation takes the form of a tremendous impact on the condition of children who are victims of sexual abuse. Therefore, law enforcers take steps to provide solutions to the problem of child sexual abuse through chemical castration. Chemical castration is expected to be a way out for the eradication of crimes of sexual violence against children, but in the process an appropriate and appropriate mechanism still needs to be formulated.

\footnotetext{
8 Tyrone B. Hayes et al., "ATRAZINE INDUCES COMPLETE FEMINIZATION AND CHEMICAL CASTRATION IN MALE AFRICAN CLAWED FROGS (XENOPUS LAEVIS)," Proceedings of the National Academy of Sciences 107, no. 10 (2010): 4612-4617, DOI: 10.1073/pnas.0909519107.

${ }^{9}$ P. A. F. Lamintang, Dasar-Dasar Hukum Pidana Indonesia (Bandung: Citra Aditya Bakti, 1997), 12.

${ }^{10}$ Moeljatno, Asas-asas Hukum Pidana (Rineka Cipta, Jakarta, 2008), 60.
} 


\section{b. Chemical Castration Position in Conviction}

Castration is a type of punishment that is quite controversial. Castration comes from the Latin word castrate which means castrate, prune, remove, or to revoke power ${ }^{11}$. Based on Law $17 / 2016$ in its consideration, stating that the background of the formation of the second amendment to the Child Protection Act is due to an increase in sexual violence against children and criminal sanctions imposed on perpetrators of sexual violence against children have not provided a deterrent effect the matter a serious crime. The deterrent effect presented in the previous law was still insufficient to reduce the rate of sexual abuse against children. Given that children are an asset of the Indonesian nation to carry on the future of the country. Children have a weaker physical condition than adults in general. So there needs to be extra protection for children so that they can develop properly and get a sense of security at all times without worrying about the condition of the community that has potential threats.

Sanctions are also given to sex offenders against children resulting in serious injuries, mental disorders, infectious diseases, disruption or loss of reproductive function. ${ }^{12}$ Additional chemical castration criminal sanctions can be applied to a judge's decision that is carried out 2 (two) years after the convicted served a basic penalty. The category of chemical castration punishment is an additional punishment, it is not a basic penalty. Therefore, there is a central role for judges in handling child sexual abuse. The proportional aspect can be seen from the conditions for the provision of chemical castration in the law. The consequences experienced by the victim include serious injuries, mental disorders and infectious diseases and reproductive disorders or functions. So the main urgency of giving chemical castration to the perpetrator is the conditions experienced by the victims. The justice aspect of handling cases of sexual harassment must be viewed in a case-based approach because it cannot be dealt with in a general and comprehensive manner, because the consequences of the perpetrators on the victims are different. So the sentence imposed must be different to ensure justice for each perpetrator. Not only aspects of justice that must be fulfilled but aspects of proportionality and aspects of the benefits of giving chemical castration punishment must also be realized.

\section{c. Legal Consequences of Chemical Castration}

In 2019, the Panel of Judges of the Mojokerto District Court imposed criminal sanctions on cases of sexual abuse and violence against children by imposing chemical castration in addition to imprisonment for 12 years, a fine of 100 million and 6 months imprisonment subsidiary (PN Mojokerto PN Decision Number 69 / Pid SUS / 2019 / PN.Mjk dated May 2, 2019) in which M. Aris, the defendant, was convicted of violating Article 76 D juncto Article 81 of Law Number 35 of 2014 concerning Amendments to Law Number 23 of 2002 regulates Child Protection (referred as Law Child protection). The decision was corroborated by Surabaya High Court Decision Number 695 / Pid.Sus / 2019 / PT SBY dated July 18, 2019. ${ }^{13}$

Based on Article 81 A paragraph (3) of Law 17/2016 states that the implementation of chemical castration is accompanied by rehabilitation. The statement explains that the main purpose of giving chemical castration as penalty, as a preventive measure so that similar incidents do not reoccur. Perpetrators of sexual crimes do not fulfill the elements of his soul that are deformed in growth or disrupted due to illness in Article 44 of the Criminal Code, but what happens is a sexual disorder in him. Based on the case in this paper, the elements in the

\footnotetext{
${ }^{11}$ Fabian M. Saleh, et al, Sex Offenders (USA: Oxford University Press, 2009), 171

12 Thomas Douglas et al., "COERCION, INCARCERATION, AND CHEMICAL CASTRATION: AN ARGUMENT FROM AUTONOMY," Journal of Bioethical Inquiry 10, no. 3 (2013): 393-405, 400, DOI: 10.1007/s11673-013-9465-4.

${ }^{13}$ Brian A. DiGangi et al., "POST-OPERATIVE OUTCOMES OF SURGICAL AND CHEMICAL CASTRATION WITH ZINC GLUCONATE IN DOGS PRESENTING TO VETERINARY FIELD CLINICS," The Veterinary Journal 229, (2017): 26-30, 26, DOI: 10.1016/j.tvj1.2017.10.016.
} 
punishment of chemical castration for the perpetrator are fulfilled, namely the conditions in which sexual abnormalities occur to the victim.

Sexual disorders can not be categorized as a mental disability, because the perpetrators of physical and mental sexual crimes are able to distinguish between good and bad, and are consciously healthy in their minds. Viewed from the criminal law, the general principle of criminal liability is personal that is imposed on the organization or the perpetrator itself (the personal principle) and only applies to the guilty person (the principle of error / the principle of culpability). That an act is deemed to have violated the law and may be subject to criminal sanctions, must be fulfilled by two elements, namely the existence of the element actus reus (physical element) and the element of mens rea (mental element).

As Aris was sentenced additional sanction of chemical castration in his last 2 years of prison, he will be castrated chemically four times because the dose of chemical drugs is only temporary and a maximum of six months. After the two years ended, the prosecutor had to take responsibility for returning Aris' manhood, so that after Aris was released, he would be back to normal. The prosecutor must also be responsible for ensuring Aris's health after being released from prison. The responsibility that must be carried out by the prosecutor is very heavy. Based on existing research, there is no certainty about the impacts that will arise in the future. The health of Aris (the perpetrator) is at stake in the handling of this case. Meanwhile, this punishment was not based on thorough and comprehensive scientific research. According to the authors this will ignore new problems and create new victims. Perpetrators can become victims and fail to restore their rights to the castration that has been enforced. The state can fail in fulfilling and protecting the rights of its citizens, even though every citizen has the same rights before the law as guaranteed by the constitution in the chapter of human rights.

IDI refuses to be the executor of castration punishment because the implementation of castration punishment by doctors is considered violating the Doctor's Oath and the Indonesian Medical Code of Ethics (Vice President respects IDI's decision to reject castration execution, Metro Bali, 10 June 2016). The rejection from IDI as viewed from the criminal law, there are two aspects, firstly the criminal procedural law regarding who is meant by the executor in the framework of the Criminal Procedure Code in Indonesia. The second is in terms of penitentiary law, namely regarding what is meant by action as a criminal form within the legal framework of the penitentiary.

The doctor is not an executor for the implementation of court decisions regarding criminal cases that have permanent legal force. In Article 1 number 6 letter a of Law No. 8 of 1981 concerning the Criminal Procedure Code (KUHAP) expressly stipulates that prosecutors are officials who are authorized by the Criminal Procedure Code to act as executors of court decisions that have obtained permanent legal force. Then in the special law (lex specialis) there is nothing that explicitly regulates the authority of a doctor who acts as the executor of a criminal court decision. If so the question then is who is the official who has the authority and ability to carry out chemical castration actions? Vice President Jusuf Kalla later stated that castration can be carried out by doctors of the Indonesian National Army (TNI) and Police doctors in accordance with his assignments as reported by Modo (2016). Of course this statement is contrary to the principles in the Criminal Procedure Code, because TNI doctors and police doctors do not have functions as executors. In this case it might be considered that a doctor who is a civil servant at the Prosecutor's Office could be considered to be given a functional position as a prosecutor to act as an executor of a court decision. But then it must be considered that there are functional differences between civil servants at the Prosecutor's Office and a prosecutor, so that if a doctor who is a civil servant at the Prosecutor's Office wants to become a prosecutor then he must take education and examinations of the prosecutor to then be appointed as a prosecutor and carry out the task of prosecution and implementation 
of court decisions that have permanent legal force. ${ }^{14}$ An unclear concept has been enforced in the application of chemical castration punishment to offenders. It appears that law enforcers are confused in determining the executor in the issue of sexual crimes against children.

The rejection from IDI as viewed from the criminal law, there are two aspects, firstly the criminal procedural law regarding who is meant by the executor in the framework of the Criminal Procedure Code in Indonesia. The second is in terms of penitentiary law, namely regarding what is meant by action as a criminal form within the legal framework of the penitentiary.

\section{Juridicial Review of Chemical Castration in Human Rights Perspective}

\section{a. Reproduction Rights and Sexual Rights}

The right to reproductive and sexual health is a derivation of human rights which is a basic right inherent in each individual and cannot be revoked. The rights of sexual and reproductive health which are part of human rights are absolute and universal so that each individual does not need any action to obtain this right because it is a unity with the individual itself. World Health Organization (WHO) has provided input regarding the definition of sexual rights, namely, sexual rights are rights that also include certain human rights that have been recognized in international and regional human rights documents and other consensus documents and in national law. ${ }^{15}$ The reproductive and sexual health rights in question also have human rights components as formulated into 12 human rights components by the International Planned Parenthood Federation (IPPF) in 1996. Based on this explanation, it explains that the right to reproduction is an absolute and inviolable right. It has been explained in detail by the competent institution in the health sector regarding the central position of the reproductive rights of a person / person. It has been strengthened and supported through documents on an international scale and has become an agreement between various countries and the international community.

IPPF outlines 12 principles that emphasize sexual and reproductive rights as basic human rights, which briefly that sexuality is an inseparable part of everyone's life. Sexuality will always be bound in the body, mind, politics, health and social order in human life. In sexual rights there is also the right to be protected from and to get protection from all forms of violence and threats related to sexual rights. Sexuality is associated with violence and physical, verbal, psychological, and economic abuse. ${ }^{16}$ Based on this explanation, it shows that the right to sexuality is very important in the human person. Various aspects of sexuality exist in various sectors of social life, both politically, in thought and in society. These matters are translated into the IPPF document through predetermined principles.

The punishment given to the perpetrators of the crime in accordance with the crime he committed. Immanuel Kant as a retributive believer apparently states that, "... we may not rape rapist, or torture tortures." ${ }^{17}$ Based on Kant's argument, we can take the understanding that the implementation of a proper sentence cannot be carried out specifically against crime related to sexual rights. Indonesia itself has abandoned its criminal objectives which use retributive theory and apply the theory of restorative justice in the conviction of someone

\footnotetext{
${ }^{14}$ IDI Polemic Rejection as Executor of Chemical Castration Act, Vidya Prahassacitta, June 2016.

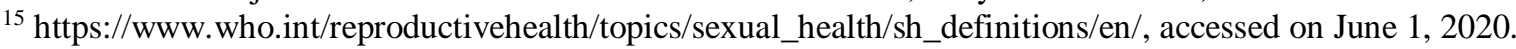

${ }^{16}$ Alice M. Miller et al., "SEXUAL RIGHTS AS HUMAN RIGHTS: A GUIDE TO AUTHORITATIVE SOURCES AND PRINCIPLES FOR APPLYING HUMAN RIGHTS TO SEXUALITY AND SEXUAL HEALTH," Reproductive Health Matters 23, no. 46 (2015): 16-30, 16, DOI: 10.1016/j.rhm.2015.11.007.

${ }^{17}$ Ibid., 6
} 
which means that punishment is carried out in order to improve the perpetrators themselves. ${ }^{18}$ In this case, the right not to be tortured and the right to be free from degrading human dignity as stipulated in the constitution are also considered. Through this theory change adopted by Indonesia, in the application of criminal punishment to the perpetrators, a consideration must be made on the improvement of the perpetrators so that the application of chemical castration is only retaliatory and not in line with the goals of Indonesian conviction.

In the chemical castration not only sexual rights are violated, John F. Stinneford gave a statement that a punishment should not enter the dimensions of one's mind, freedom to think is a person's autonomy and personality ${ }^{19}$ while chemical castration eliminates the ability to control or autonomy someone for their reproductive organs and sexual will. chemical castration which changes a person's desires, which enters the dimension of mind which if violated his rights will not only violate morals but also the law as a form of mind manipulation. Initially, the aim was to protect the victim, but now castration is cruel to the perpetrator. Law enforcers and legislators forget that there are perpetrators' rights that need to be protected. The perpetrator is a person who can still change into a better person, law enforcement officers are very positivist and walk without conscience as a human being. The law is seen as transgressing and arbitrary in matters of sexual violence against children. Children are indeed subjects that must be protected maximally but not at the expense of the perpetrator to be treated inhumanely.

\section{b. Chemical Castration Comparation in the World}

Chemical castration is part of penalty regulations in several countries including the United States, South Korea, ${ }^{20}$ and Russia. South Korea became the first country in Asia to legalize castration penalties in 2011. The law was passed in July of that year and allowed castration injections on sexual crime defendants over the age of 19. In 9 states in United States of America, including California, Florida, and Washington, has implemented castration penalties, but the chemical used for castration has never been approved by FDA to be used as a treatment for sexual offenders. And in Russia, chemical castration has been used for child sex offenders, and the perpetrators must be declared as a pedophile by a panel of doctors. ${ }^{21}$ Some of these countries determine the existence of detailed characteristics, such as the determination of the age threshold for chemical castration punishment, then the classification of the perpetrator as a pedophile so that he can be given chemical castration punishment for himself. In contrast to Indonesia, which it does not include specific characteristics for determining punishment of castration. There are still legal loopholes that have the potential to injure the rights of the perpetrators. Things like this must be an aspect that needs to be improved in reformulating the mechanism and further policy formulation so that the law can adapt to the current situation.

There are three ways that are widely used to categorize these regulations, the first way is when the administration of chemical castration as a form of treatment, which can be "voluntary", ${ }^{22}$ in which the perpetrator has an awareness or even a request from the

\footnotetext{
${ }^{18}$ Thomas W. Johnson et al., "EUNUCHS IN CONTEMPORARY SOCIETY: CHARACTERIZING MEN WHO ARE VOLUNTARILY CASTRATED (PART I)," The Journal of Sexual Medicine 4, no. 4 (2007): 930945, 932, DOI: 10.1111/j.1743-6109.2007.00521.x.

${ }^{19}$ Ibid., 10

${ }^{20}$ Firas L. Tarish et al., "CASTRATION RADIOSENSITIZES PROSTATE CANCER TISSUE BY IMPAIRING DNA DOUBLE-STRAND BREAK REPAIR," Science Translational Medicine 7, no. 312 (2015): 1-6, 2, DOI: 10.1126/scitranslmed.aac5671.

${ }^{21}$ Buchari, Rd \& Sumaryana, Asep \& Andari, Rosita, "AN ALTERNATIVE MODEL OF CHILD SEXUAL ABUSE HANDLING POLICY IN INDONESIA”, Sosiohumaniora 19, no. 3 (2017): 260-267, 260.

${ }^{22}$ Nisrina Nurul Insani, Bambang Poerwantoro, and Zuhroni Zuhroni, "PERSPEKTIF MAHASISWA FAKULTAS PSIKOLOGI ANGKATAN 2015 UNIVERSITAS YARSI JAKARTA PUSAT TERHADAP
} 
perpetrator as a therapeutic effort. Voluntarily means that chemical castration will only be considered, and will be lawful, if a person is found guilty of certain types of violations and gives his consent to the treatment. The first method is used in several countries, such as England and Denmark. Second, the regulation of chemical castration is discretion. Chemical castration can be a penalty option that can be handed down by a court if someone has been convicted of certain violations, along with other sentences (such as prison), but the court did not have to impose the additional sentence. If the court enforces it as a punishment, then the person convicted must undergo the chemical castration. ${ }^{23}$ The third and final way, namely the regulation of chemical castration is an obligation. If someone is convicted of a particular type of offense, the court must impose chemical castration (and other penalties, such as prison). Specifically, the law stipulates that penalties involving chemical castration must be carried out when the offender returns to the offense. ${ }^{24}$ The application of chemical castration punishment in Indonesia, determination of chemical castration punishment is carried out through the aspect of discretion, because it involves the judge in the process in court. Judges are required to be wise in assessing every case regarding violations of child sexual abuse. The aspect of justice really rests on the hands of the judge in deciding a case. Of course this still has weaknesses, considering that the quality of judges in Indonesia is not overall of good quality.

From several comparisons of these countries, it is known that several countries use both methods in applying the chemical castration, first method, perpetrators voluntarily asked for chemical castration. Second, the regulation of chemical castration is discretion. Chemical castration can be a penalty option that can be handed down by a court if someone has been convicted of certain violations, along with other sentences (such as prison). The author, in this case, sees better options regarding the mechanism of applying chemical castration punishment to the perpetrators. Voluntary model as applied in Denmark and the UK. The author chose this mechanism because the potential for human rights violations to occur is smaller. Perpetrators have the freedom to choose two options; first, willing to give chemical castration punishment according to the various risks involved; second, he refused to be punished with chemical castration with the consequence that he had to seriously change into a better person. This voluntary mechanism has a good impact on law enforcement in its legal culture aspects. Legal culture is formed naturally and is not enforced, this can minimize the potential for new crimes to arise and new unexpected problems due to the very forced chemical castration penalty.

\section{d. Chemical Castration as Criminal Sanction or Therapeutic Options}

In the comparison of chemical castration in several countries, it is known that several countries use chemical castration as a therapeutic effort. Chemical castration should be carried out as a rehabilitation or treatment, or as a therapeutic attempt to perpetrate sexual offenses rather than as convictions. ${ }^{25}$ Castration can chemically damage or even undermine the function of organs, namely diminishing muscle function, osteoporosis, reducing the number

\footnotetext{
APLIKASI CHEMICAL CASTRATION (KEBIRI) BAGI PELAKU KEKERASAN SEKSUAL ANAK DI INDONESIA DAN TINJAUANNYA MENURUT ISLAM," Jurnal Profesi Medika : Jurnal Kedokteran Dan Kesehatan 12, no. 2 (2018): 53-59, 53, DOI: 10.33533/jpm.v12i2.274.

${ }^{23}$ L.T. Martins et al., "CASTRATION METHODS DO NOT AFFECT WEIGHT GAIN AND HAVE DIVERSE IMPACTS ON THE WELFARE OF WATER BUFFALO MALES,” Livestock Science 140, no. 1-3 (2011): 171-176, 172, DOI: 10.1016/j.livsci.2011.03.026.

${ }^{24}$ Kyo Chul Koo et al., "EFFECTS OF CHEMICAL CASTRATION ON SEX OFFENDERS IN RELATION TO THE KINETICS OF SERUM TESTOSTERONE RECOVERY: IMPLICATIONS FOR DOSING SCHEDULE," The Journal of Sexual Medicine 11, no. 5 (2014): 1316-1324, 1317, DOI: 10.1111/jsm.12492.

${ }^{25}$ United Nations Country Team in Turkey (UNCT), White Paper Chemical Castration and Life Imprisonment as Measures to Punish Sexual Crimes against Children, 1.
} 
of red blood cells, and disrupting the function of other cognitive organs. ${ }^{26}$ The side effects that are very detrimental to the perpetrators of crimes of sexual violence against children, the state must reconsider the existence of chemical castration punishment in the Indonesian criminal system. The current mechanism still needs to be refined so that Indonesian criminal law is in line with the constitution and legislation as a whole both nationally and internationally.

The implementation of chemical castration without the full agreement of the perpetrators is tantamount to violating international law regarding human rights, especially in the following articles Article 7 of Law Number 12 Year 2005 concerning Ratification of the International Convenant on Civil and Political Rights (referred as the Law on Political Rights), Article 5 of the Universal Declaration of Human Rights (UDHR), and Article 1 of the Republic of Indonesia Law Number 5 Year 1998 concerning Ratification of the Convention Against Torture and Other Cruel, Inhuman or Degrading Treatment or Punishment (referred as Law 5/1998). The author considers that the chemical castration penalty in the current law is a violation of human rights. Although this punishment is a type of crime, each punishment has a justification for its application so that it is not included in an illegal act. Criminal penalties at the statutory level can still be readjusted to the constitution if they are contrary to legal principles and general legal principles and the rules in law are not final. There needs to be progressive and innovative efforts to reformulate chemical castration punishment for perpetrators of child sexual abuse. Of course, these efforts must be based on comprehensive and scientific research to reduce any risks that will arise in the future.

From the provisions of the article above shows that every person has the right to be free from inhumane punishment and degrading human dignity and status, in this case chemical castration is very contrary to Article 7 because at the time of application of chemical castration, the treatment carried out is inhumane or demeaning of someone. Article 5 also explains that the chemical castration is not in accordance with the regulations above because in the implementation of the person at the time of punishment will be treated inhumanely. ${ }^{27}$ Respect for human rights must be upheld in a rule of law, especially Indonesia, which has declared a rule of law after reform. Chemical castration needs to be reviewed and reformulated to conform to humanitarian principles, because an obligatory requirement of a rule of law is protection and respect for human rights.

Castration punishment actually makes the perpetrators more aggressive and cannot guarantee the recurrence of criminal acts sexual because sexual memory is still attached to the mind of the perpetrator, even though the hormone testosterone decreases, so it is feared that it will even lead to a new crime. Therefore, chemical castration does fulfill its duty in reducing sexual recidivities, but does not necessarily make it a cure for sexual offenders who commit crimes due to mental disorders they have. In addition, the relationship between chemical castration and sexual rights has also been explained above that sexual rights cannot be erased, which means that the state cannot impose a sanction that makes someone lose their sexual rights.

If there is no guarantee that the imposition of chemical castration will reduce recidivists from sexual crimes against children, then castration is not necessary. However, the effect that will be felt by the perpetrator has the potential to endanger his survival. Chemical castration punishment will be one of the criminological factors for new types of crimes that will emerge

\footnotetext{
${ }^{26}$ Imas Novita Juaningsih, "ANALISIS PENEGAKAN KEBIRI KIMIA BAGI PELAKU TINDAK PIDANA KEKERASAN SEKSUAL PADA ANAK DI BAWAH UMUR,” Journal of Legal Research 1, no. 6 (2020): 1-6, 1 DOI: $10.15408 /$ jlr.v1i6.15092.

27 Michael E. Jung et al., "STRUCTURE-ACTIVITY RELATIONSHIP FOR THIOHYDANTOIN ANDROGEN RECEPTOR ANTAGONISTS FOR CASTRATION-RESISTANT PROSTATE CANCER (CRPC)," Journal of Medicinal Chemistry 53, no. 7 (2010): 2779-2796, 2779, DOI: 10.1021/jm901488g.
} 
in the future, because the current chemical castration punishment is a punishment that does not consider the aspects of benefit and only focuses on revenge against the perpetrator.

The implementation of chemical castration that changes the human mind is also an act that changes a person's body through the play of hormones in his body. Changes in the body that result in changes in the desires of a person if they do not get approval from the perpetrators of the crime that will be castrated with the chemical will violate a person's right, namely the right to resist manipulation of his body. Chemical castration should be considered as a theurapetic effort so that actors can choose or request chemical castration as a rehabilitation option. Paying back crimes with cruel actions is a concept that has been abandoned in today's modern times, when bad things happen, the country will find it very difficult to recover. The body of an offender that has been damaged by chemical castration will be very difficult to restore. If that happens, then the state can fail to protect and fulfill the rights of its citizens.

The law stated in the preamble to the 945 Constitution will fail to be achieved, namely that the state is obliged to protect the entire Indonesian nation and all its blood spills. According to the author, this punishment is a law enforcement effort that does not prioritize aspects of humanity, aspects of proportionality, and aspects of justice and is not a solution in finding a way out. The ideal punishment should be able to solve problems and not cause new problems in the future. All of these efforts will be in vain if the punishment given will create a new situation and a new, more terrible crime in the future. The solution to this problem is to place chemical castration punishment in the corridor of rehabilitation and prioritize the principle of freedom in choosing punishment for the perpetrators.

\section{Conclusion}

In terms of human rights of sexual offenders, chemical castration violates human rights based on Article 7 of Law Number 12 Year 2005 regulates Ratification of the International Convenant on Civil and Political Rights and in Article 5 of the Universal Declaration of Human Rights. Chemical castration is a punishment that does not consider aspects of justice for the perpetrator. Perpetrators as citizens have rights guaranteed by the constitution and laws. The chemical castration punishment focuses more on restoring the rights of the victims, but not on restoring the rights of the perpetrators. The proportionality aspect that is trying to be realized is considered to be out of date due to the impact of chemical castration which cannot be predicted according to incomplete scientific research. The mechanisms that are regulated are not specific and detailed, such as determining the characteristics of the perpetrator who should be given chemical castration punishment, determining the executor, and other unclear aspects. Therefore, in this case the chemical castration should be done by means of treatment in rehabilitation, not as a punishment, taking into account human rights and the effectiveness of the chemical castration with the consent of the sexual offender. The solutions offered by the author could be better and consider aspects of human rights. If chemical castration is done voluntarily, chemical castration will not have the potential for new crimes with a different model. The government must reformulate the chemical castration punishment in Indonesia's criminal system. 


\section{A. Journal}

\section{REFERENCES}

DiGangi, Brian A., et.al. "POST-OPERATIVE OUTCOMES OF SURGICAL AND CHEMICAL CASTRATION WITH ZINC GLUCONATE IN DOGS PRESENTING TO VETERINARY FIELD CLINIcs.” The Veterinary Journal 229, 2017: 26-30, DOI: 10.1016/j.tvj1.2017.10.016.

Douglas, Thomas, et.al. "COERCION, INCARCERATION, AND CHEMICAL CASTRATION: AN ARGUMENT FROM AUTONOMY." Journal of Bioethical Inquiry 10, no. 3, 2013: 393-405, DOI: 10.1007/s11673-013-9465-4.

Hayes, Tyrone B., et al. "ATRAZINE INDUCES COMPLETE FEMINIZATION AND CHEMICAL CASTRATION IN MALE AFRICAN CLAWED FROGS (XENOPUS LAEVIS)." Proceedings of the National Academy of Sciences 107, no. 10, 2010: 46124217, DOI: 10.1073/pnas.0909519107.

Insani, Nisrina Nurul., Poerwantoro, Bambang., Zuhroni. "PERSPEKTIF MAHASISWA FAKULTAS PSIKOLOGI ANGKATAN 2015 UNIVERSITAS YARSI JAKARTA PUSAT TERHADAP APLIKASI CHEMICAL CASTRATION (KEBIRI) BAGI PELAKU KEKERASAN SEKSUAL ANAK DI INDONESIA DAN TINJAUANNYA MENURUT ISLAM." Jurnal Profesi Medika: Jurnal Kedokteran Dan Kesehatan 12, no. 2, 2018: 53-59, DOI: 10.33533/jpm.v12i2.274.

Johnson, Thomas W., et.al. "EUNUCHS IN CONTEMPORARY SOCIETY: CHARACTERIZING MEN WHO ARE VOLUNTARILY CASTRATED (PART I)." The Journal of Sexual Medicine 4, no. 4, 2007: 930-945, DOI: 10.1111/j.17436109.2007.00521.x.

Juaningsih, Imas Novita. "ANALISIS PENEGAKAN KEBIRI KIMIA BAGI PELAKU TINDAK PIDANA KEKERASAN SEKSUAL PADA ANAK DI BAWAH UMUR." Journal of Legal Research 1, no. 6, 2020: 1-6, DOI: 10.15408/jlr.v1i6.15092.

Jung, Michael E., et.al. "STRUCTURE-ACTIVITY RELATIONSHIP FOR THIOHYDANTOIN ANDROGEN RECEPTOR ANTAGONISTS FOR CASTRATION-RESISTANT PROSTATE CANCER (CRPC).” Journal of Medicinal Chemistry 53, no. 7, 2010: 2779-2796. DOI: 10.1021/jm901488g.

Kartono, Kartono, and Aji Mulyana. "THE IMPLEMENTATION OF CHEMICAL CASTRATION PENALTIES TOWARDS PAEDOPHILIA CRIME PERPETRATORS." Fiat Justisia: Jurnal Ilmu Hukum 13, no. 4, 2019: 321-332, DOI: 10.25041/fiatjustisia.v13no4.1683.

Koo, Kyo Chul., et.al. "EFFECTS OF CHEMICAL CASTRATION ON SEX OFFENDERS IN RELATION TO THE KINETICS OF SERUM TESTOSTERONE RECOVERY: IMPLICATIONS FOR DOSING SCHEDULE." The Journal of Sexual Medicine 11, no. 5, 2014: 1316-1324, https://doi.org/10.1111/jsm.12492.

Krismiyarsi, Krismiyarsi. "STUDY OF PENAL POLICY ON CHEMICAL CASTRATION SANCTION ON CHILD SEXUAL CRIMES CASES IN INDONESIA." IJCLS (Indonesian Journal of Criminal Law Studies) 3, no. 2, 2018: 121-132, DOI: 10.15294/ijcls.v3i2.17171.

Martins, L.T., et al. "CASTRATION METHODS DO NOT AFFECT WEIGHT GAIN AND HAVE DIVERSE IMPACTS ON THE WELFARE OF WATER BUFFALO MALES." Livestock Science 140, no. 1-3, 2011: 171-176, DOI: 10.1016/j.livsci.2011.03.026.

Miller, Alice M., et.al. "SEXUAL RIGHTS AS HUMAN RIGHTS: A GUIDE TO AUTHORITATIVE SOURCES AND PRINCIPLES FOR APPLYING HUMAN RIGHTS TO SEXUALITY AND SEXUAL HEALTH." Reproductive Health Matters 23, no. 46, 2015: 16-30, DOI: 10.1016/j.rhm.2015.11.007.

Ratkoceri, Vedije. "CHEMICAL CASTRATION OF CHILD MOLESTERS - RIGHT OR 
WRONG?!" European Journal of Social Sciences Education and Research 11, no. 1, 2017: 70-76, DOI: 10.26417/ejser.v11i1.p70-76.

Tarish, Firas L., et.al. "CASTRATION RADIOSENSITIZES PROSTATE CANCER TISSUE BY IMPAIRING DNA DOUBLE-STRAND BREAK REPAIR." Science Translational Medicine 7, no. 312, 2015: 1-6, DOI: 10.1126/scitranslmed.aac5671.

Usfunan, Yohanes, Usfunan, Jimmy Z., Putra, IPR. Arsha. "THE CONSTITUTIONALITY OF CASTRATION SANCTION." Udayana Journal of Social Sciences and Humanities (UJoSSH) 1, no. 1, 2017: 121-126, DOI: 10.24843/UJoSSH.2017.v01.i01.p20.

Zhuang, Jin. "CHEMICAL CASTRATION: INTERNATIONAL EXPERIENCE AND CHINESE PATH TO CONTROL PEDOPHILIA CRIMES." Advances in Applied Sociology 8, no. 8, 2018: 575-597, DOI: 10.4236/aasoci.2018.88034.

\section{B. Books}

Hamzah, Jur Andy, Asas-asas Hukum Pidana. Jakarta: Rineka Cipta, 2008.

Lamintang, P.A.F. Dasar-Dasar Hukum Pidana Indonesia. Bandung: Citra Aditya Bakti, 1997.

Marzuki, Peter Mahmud. Penelitian Hukum. Jakarta: Kencana, 2005.

Moeljatno. Asas-Asas Hukum Pidana. Jakarta: Rineka Cipta, 2008.

Saleh, Roeslan, Stelsel Pidana Indonesia. Jakarta: Aksara Baru, 1983.

Saleh, Fabian M. etal. Sex Offenders. USA: Oxford University Press, 2009.

\section{Internet}

http://metrobali.com/wapres-menghormati-keputusan-idi-tolak-eksekusi-kebiri/, accessed on June 10, 2016.

https://nasional.tempo.co/read/1231780/ada-236-kasus-pelecehan-seksual-anak-sepanjang2019, accessed on August 3, 2019. 
